member of the Clothworkers' Company to the Department of Biomolecular Structure, to be devoted to the furtherance of cancer research carried on under the direction of Prof. W. T. Astbury ; $£ 2,000$ from the Central Electricity Authority to the Department of Agriculture, to continue during 1956-57 research on the reclamation of ash lands; $£ 6,000$ a year for two years from the Nuffield Foundation to the Department of Medicine, in support of the gerontological research unit.

\section{Institution of Electrical Engineers: Officers}

THE following will take office on the Council of the Institution of Electrical Engineers on September 30 next : President, Sir Gordon Radley; VicePresidents, T. E. Goldup, S. E. Goodall, Dr. Willis Jackson, G. S. C. Lucas and Sir Hamish D. MacLaren; Honorary Treasurer, Rt. Hon. Viscount Falmouth; New Members of Council, J. A. Broughall, B. Donkin, A. H. Mumford, D. P. Sayers, H. Watson-Jones and H. West.

\section{The Night Sky in August}

NEw moon occurs on Aug. 6d. 11h. 25m., U.T., and full moon on Aug. $21 \mathrm{~d} .12 \mathrm{~h} .38 \mathrm{~m}$. The following conjunctions with the Moon take place: Aug. 3d. 13h., Venus $3^{\circ}$ S. ; Aug. 7d. 22h., Mercury $6^{\circ}$ N.; Aug. 8d. 03h., Jupiter $6^{\circ}$ N. ; Aug. 13d. 21h., Saturn $3^{\circ}$ N. ; Aug. 23d. 21h., Mars $12^{\circ} \mathrm{S}$. In addition to these conjunctions with the Moon, Mercury is in conjunction with Regulus on Aug. 5d. 04h., Mercury $0.9^{\circ} \mathrm{N}$., and is also in conjunction with Jupiter on Aug. 9d. 18h., Mercury being then only $0 \cdot 2^{\circ} \mathrm{S}$. of Jupiter. Mercury is too close to the Sun for observation during August. Venus rises at $1 \mathrm{~h}$. $35 \mathrm{~m}$. at the beginning of the month and at $1 \mathrm{~h} .15 \mathrm{~m}$. at the middle and end of the month; its stellar magnitude varies between $-4 \cdot 2$ and $-\mathbf{4 . 4}$ and the visible portion of its illuminated disk increases from $0 \cdot 297$ to 0.492 , its distance from the Earth increasing from 44 to 65 million miles. Mars rises at $21 \mathrm{~h}$. $45 \mathrm{~m}$., $20 \mathrm{~h}$. $50 \mathrm{~m}$. and $19 \mathrm{~h} .50 \mathrm{~m}$. on August 1, 15 and 31 , respectively, and during the month its brightness increases in magnitude from $-1 \cdot 8$ to $-2 \cdot 5$, the visible portion of its illuminated disk increasing from 0.930 to 0.991 and its distance from the Earth decreasing from 43 to $35 \frac{1}{2}$ million miles. Jupiter is too close to the Sun during August for favourable observation. Saturn can be observed for a short time after sunset, its times of setting being $23 \mathrm{~h} .25 \mathrm{~m}$., $22 \mathrm{~h}$. $30 \mathrm{~m}$. and $21 \mathrm{~h} .30 \mathrm{~m}$. at the beginning, middle and end of the month, respectively; its stellar magnitude remains about 0.7 , while its distance from the Earth varies from 896 to 942 million miles. It has a slow eastward movement in Libra, and at the end of the month it is about $5^{\circ}$ south-east of $\gamma$ Libr $x$. The Perseid meteors attain a maximum about August 10-13, the radiant being at R.A. $3 \mathrm{~h} .8 \mathrm{~m}$., Dec. $58^{\circ} \mathrm{N}$.

\section{Announcements}

THE Scottish Agricultural Industries, Ltd., postgraduate studentship at the University of Aberdeen has been awarded to $R$. Bain, who will work on the sorption of polyelectrolytes on mercury and on clay mineral surfaces.

The Alvarenga Prize for 1956 of the College of Physicians of Philadelphia has been awarded to Dr. George N. Papanicoloau, director of the Papanicoloau Research Laboratory of Cornell University Medical College, for his outstanding work in the early. detection of cancer.
Dr. Albert H. Moseman, formerly director of crops research in the United States Department of Agriculture Research Service, has been appointed associate director for agriculture of the Rockefeller Foundation. Dr. Moseman's activities will be associated with Foundation grants to institutions in the United States for fundamental research in agriculture, and ageicultural programmes in foreign countries. He will work in association with Dr. J. George Harrar, director for agriculture.

THE University of Oxford has received from the Medical Research Council a grant of $£ 3,655$ for the continuation of research into the effects of the injection of radioactive substances being carried out in the Nuffield Department of Medicine by Dr. J. M. Vaughan, principal of Somerville College, and $£ 2,000$ for the equipment of a hutted laboratory for use by Dr. Vaughan.

THE Chemical Research Laboratory, Teddington, will hold its open days this year on October 2 (afternoon only) and October $3-4$. Applications for tickets should be made to the Director before August 31 . Those already on the mailing list need not re-apply.

The second of the congresses on theoretical and applied mechanics, sponsored by the Council of Scientific and Industrial Research, India, will be held during October 15-16 in the National Physical Laboratory, New Delhi, under the presideney of Sir K. S. Krishnan. Research papei's may be contributed on any of the following topics : elasticity, plasticity and rheology; fluid mechanics (aerodynamics and hydrodynamics); mechanies of solids (ballistics, vibrations, friction and lubrication); statistical meshanics, thermodynamics and heat transfer ; mathematics of physics and mechanics, and methods of computation. Such papers, with three copies of abstracts, must be sent before August 15. All correspondence should be addressed to the secretary. treasure: of the congiess, Dr. B. R. Seth, Indian Institute of Technology, Kharagpur.

THE Socioty for Water Treatment and Examina. tion will hold its autumn meeting in the Wills Hall, University of Bristol, during September 19-21. In view of the great interest shown as a result of the publication of the third edition (1956) of "The Bacteriological Examination of Water Supplies" (Report No.. 71), the Society will hold another meeting in London on November 20 (5.30-8.30 p.m.) in the Library of the Royal Society of Health, to which the Society of Applied Bacteriology, the Microbiological Section of the Society of Chemical Industry and the Institution of Water Engineers have been invited. Further information on both these meetings can be obtained from the honorary secretary of the Society, A. W. H. MeCanlis, 41 Carshalton Road, Sutton, Surrey.

THE Department of Medical Chemistry of the Australian National University (with Prof. Adrien Albert in charge) will be transferred from London to the newly built John Curtin School of Medical Research in Canberra on August 10.

Erratum. In a communication entitled "Dependence of Snowfall on Temperature", by L. W. Gold and G. P. Williams, in Nature of June 16, p. 1137, it was erroneously implied that Prof. M. Bossolasco correlated frequency of occurrence of snowfall with mean daily temperature; in fact, his correlation was between frequency of occurrence of snowfall and the temperature at the time of fall. 